\title{
A Patient of Short Stature with Normal GH Secretion, but a Low Serum IGF-I Level
}

\author{
Daishi MOCHIZUKI, Hiroko KODAMA, Kazuoimi KUbOTA, Yosuke MORI, Natsue NAKaMOTO, \\ MASAAKI KOBAYASHI, YUKISHIge YANAGAWA AND MASAYUKI KAJI*
}

Department of Pediatrics, Teikyo University School of Medicine2-11-1 Kaga, Itabashi-ku, Tokyo 173-8605 Japan

* Division of Endocrinology and Metabolism, Shizuoka Children's Hospital

\begin{abstract}
We report the case of a 7-year-old patient of short stature who had normal GH secretion, but a very low serum IGF-I level. On admittance, his height and weight were $102.2 \mathrm{~cm}(-3.8 \mathrm{~S} . \mathrm{D}$.) and $15.7 \mathrm{~kg}(-1.8 \mathrm{~S}$.D)., respectively. His bone age was 2 years and 8 months. The serum GH responses to insulin, glucagon and L-dopa were all normal. GH secretion during sleep was also normal, but the serum IGF-I level was very low $(29 \mathrm{ng} / \mathrm{ml})$. The serum IGF-I level was greatly increased by the administration of GH. No mutation was detected in the GH-1 gene. His height velocity was noticeably improved by GH treatment.
\end{abstract}

Key words: Short Stature, Normal GH secretion, Low serum IGF-I, GH-1 gene, GH therapy

(Endocrine Journal 47: S125-S127, 2000)

PATIENTS of very short stature, with normal GH secretion but a low serum IGF-I level, are rare. In some cases, the short stature results from a mutation in the GH-1 gene or from abnormalities in the GH receptor [1-4]. We report here a patient of short stature who had normal GH secretion, but a very low serum IGF-I level. His height velocity was noticeably improved by $\mathrm{GH}$ treatment.

\section{Case Report}

A 7-year-old boy was admitted to our hospital because of short stature. His father and mother are 163 and $160 \mathrm{~cm}$ tall, respectively. There are no other family members of short stature. The patient was the product of a full-term normal delivery. The birth weight and height were $2,652 \mathrm{~g}$ and $48 \mathrm{~cm}$, respectively. His upper left eyelid was ptotic. His mental and psychomotor development was normal.

Correspondence to: Hiroko KODAMA, M.D., Department of Pediatrics, Teikyo University School of Medicine, 2-11-1 Kaga, Itabashi-ku, Tokyo 173-8605, Japan
Short stature was noticed at the age of 1 year and gradually became more prominent. On admittance, his height was $102.2 \mathrm{~cm}(-3.8 \mathrm{SD})$, and his weight was $15.7 \mathrm{~kg}(-1.8 \mathrm{SD})$. The upper left eyelid was ptotic. Further physical examinations showed no abnormalities. A complete blood count, routine blood chemical tests and serologic tests were all normal. The serum levels of TSH, freeT4, freeT3, $\mathrm{LH}$, FSH and testosterone were also normal. The serum IGF-I level was very low at $29 \mathrm{ng} / \mathrm{ml}$. His bone age was 2 years and 8 months at the chronological age of 7 years. Brain CT scan and MRI revealed no abnormalities. As shown in Table 1, the serum GH responses to the administration of insulin, L-dopa and glucagon were all normal. The mean serum GH level during sleep was $18.8 \mathrm{ng} / \mathrm{ml}$. The change in the serum IGF-I level that occurred in response to GH administration is shown in Figure 1. The serum IGF-I level increased to about $120 \mathrm{ng} / \mathrm{ml}$ as a result of $\mathrm{GH}$ administration. In view of this response, $\mathrm{GH}$ therapy $(0.5 \mathrm{U} / \mathrm{kg} /$ week $)$ was started at the age of 7 years, and, as a result, his height velocity improved to $9.5 \mathrm{~cm}$ /year (Fig. 2). The serum IGF-I level and his bone age also improved with the therapy. When 
Table 1. Endocrinological data of the patient

\begin{tabular}{cccccccccccc}
\hline & & & \multicolumn{2}{c}{$\begin{array}{c}\text { Serum GH }(\mathrm{ng} / \mathrm{ml}) \\
\text { Basal }\end{array}$} & & \multicolumn{2}{c}{ Peak in stimulation tests } & & \multicolumn{2}{c}{ TSH response to } & \multicolumn{3}{c}{ Responses to LH-RH (mIU/ml) } \\
& Insulin & L-Dopa & Glucagon & GRF & Basal & Peak & Basal & Peak & Basal & Peak \\
\hline 2.6 & 17 & 15 & 25 & 64 & 0.63 & 9.18 & 0.1 & 3.7 & 0.8 & 7.8 \\
\hline
\end{tabular}

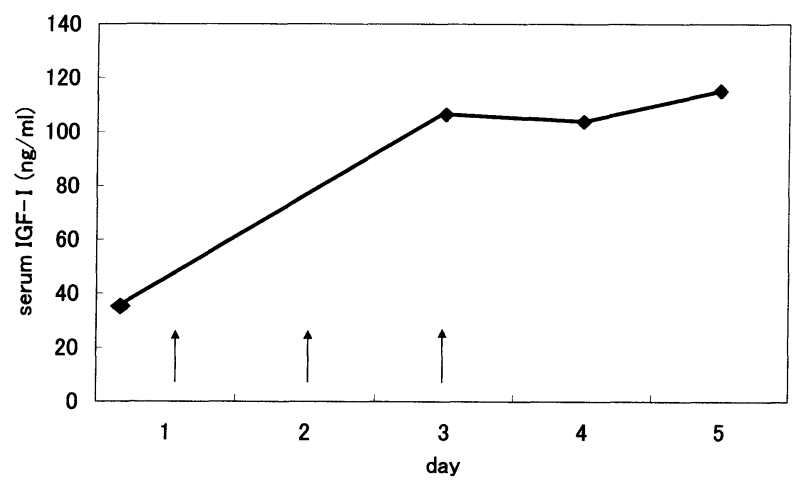

Fig. 1. $\mathrm{GH}(0.1 \mathrm{U} / \mathrm{kg})$ was subcutaneously administered on 3 consecutive days $(\uparrow)$; the serum IGF-I level was examined prior to administration and on the $3 \mathrm{rd}$, 4th and 5 th days.

he was 9 years and five months old, GH treatment was discontinued for 3 months, because his family were moving to another house. During that period, he remained well, but his height did not increase at all. After the resumption of $\mathrm{GH}$ treatment, his height began increasing again. No adverse effects of GH treatment have been observed in this patient. GH-1 Gene Analysis: Genomic DNA was isolated from the patient's lymphocytes. GH-1 gene analysis was performed as described elsewhere [2]. No mutation was detected in the GH-1 gene of this patient.

\section{Discussion}

This patient has normal GH responses to pharmacological stimuli as well as normal spontaneous GH secretion. In addition, the short stature was extreme, and his bone age was also greatly retarded. These findings indicate that he has no GH neurosecretory dysfunction [5]. The laboratory data and the effect of $\mathrm{GH}$ administration on this patient suggest that his endogenous $\mathrm{GH}$ is biologically inactive and that he might have a mutation in the GH-1

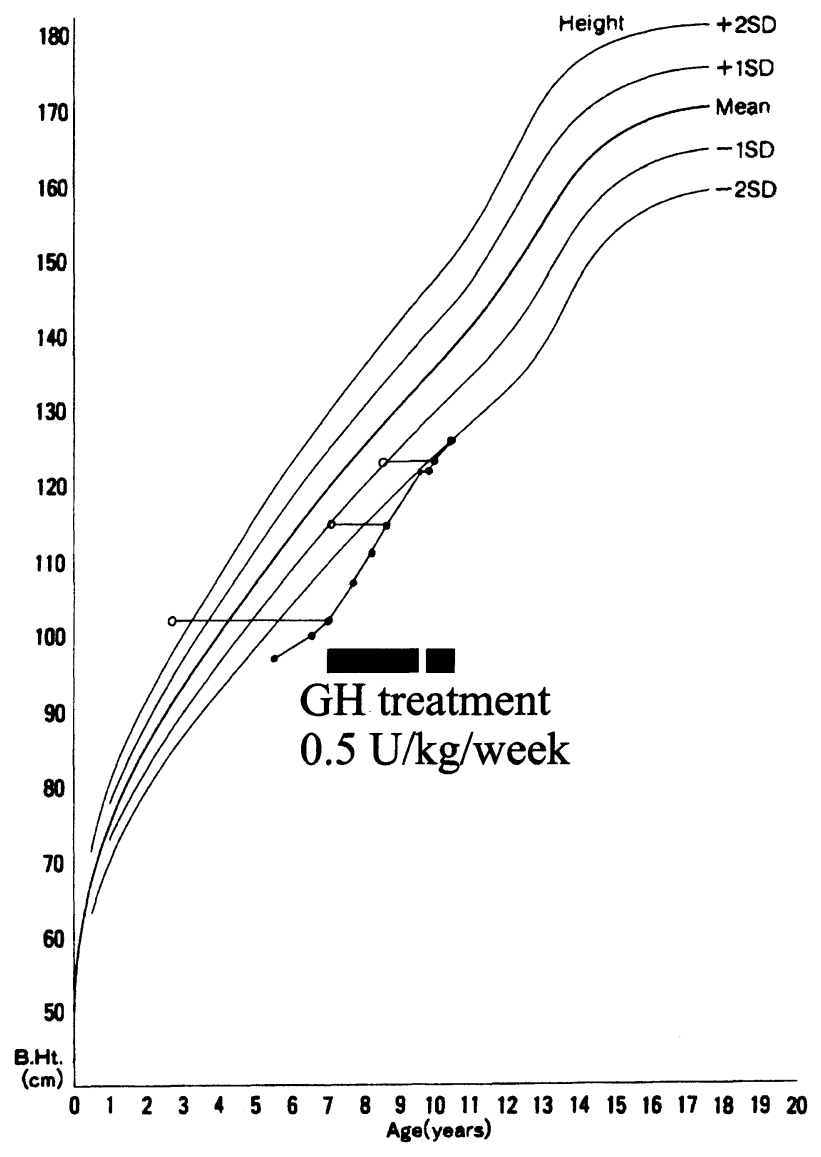

Fig. 2. Patient's growth chart. His growth (closed circles) was greatly improved by $\mathrm{GH}$ treatment. Open circles indicate his bone age.

gene. Mutations in the GH-1 gene have been reported in some patients of short stature with normal GH secretion but a low serum IGF-I level [1, 2]. We analyzed the GH-1 gene of this patient and found no mutation in it. Measurement of the biological activity of $\mathrm{GH}$ in this patient is now in progress.

\section{Acknowledgements}

We thank Drs. Y. Takahashi and K. Iida of the 
Third Division, Department of Medicine, Kobe University School of Medicine, for analyzing the
GH-1 gene.

\section{References}

1. Takahashi Y, Kaji H, Okimura Y, Goji K, Abe H, Chihara K (1996) Short stature caused by a mutant growth hormone. N Eng J Med 334: 432-436.

2. Takahashi Y, Shirono H, Arisaka O, Takahashi K, Yagi T, Koga J, Kaji H, Okimura Y, Abe H, Tanaka T, Chihara K (1997) Biologically inactive growth hormone caused by an amino acid substitution. J Clin Invest 100: 1159-1165.

3. Goddard AD, Covello R, Luoh SM, Clackson T, Attie KM, Gesundheit N, Rundle AC, Wells JA, Carlsson LMS (1995) Mutations of the growth hormone receptor in children with idiopathic short sta- ture. N Eng J Med 333: 1093-1098.

4. Woods KA, Fraser NC, Postel-Vinay MC, Savage MO, Clark AJL (1996) A homozygous splice site mutation affecting the intracellular domain of the growth hormone receptor resulting in Laron syndrome with elevated GH-binding protein. J Clin Endocrinol Metab 81: 1686-1690.

5. Spiliotis BE, August GP, Hung W, Sonis W, Mendelson W, Bercu BB (1984) Growth hormone neurosecretory dysfunction: a treatable cause of short stature. JAMA 251: 2223-2230. 